\title{
RESEARCH OF PHYSIOMETRIC INDICATORS OF FEMALE STUDENTS FROM TRAKIA UNIVERSITY
}

\author{
P. Angelova*, P. Petkov \\ Medical College, Trakia University, Stara Zagora, Bulgaria
}

\begin{abstract}
Reliable data on physical fitness and determination of the functional state of the body reflect the level of physical capabilities and the level of development of motor skills. Objective: Determination of individual physiometric indicators in students. Contingent: 130 female students of Trakia University. The average value of the vital capacity in the studied students is 3,60 , and vital indicator 61,61 . With the left and right hand dynamometer, mean right hand values of $15,46 \mathrm{~kg}$ were found, and left $-12,76$ $\mathrm{kg}$. Force strength is set at $63,42 \mathrm{~kg}$. Conclusion: The relative share of students with low values of the vital capacity is high, the values for dynamometry force are also low; there is a disproportion between good physical development due to acceleration factors and recorded retention or deterioration of physical capacity.
\end{abstract}

Key words: physical development, students, dynamometry, vital capacity

\section{INTRODUCTION}

The daily life of the students is characterized by information overload, lack of time, hypodynamia, and this of course can worsen their health (1-3). According to some authors $(4,5)$, the specific workload at certain universities can put the process described above as a serious problem. They point out as an additional factor the decrease in physical indicators in the third and fourth year, compared to the first and second year. At the present time is accepted that the assessment of health status should include morphological, functional, somatic and psychological indicators of the state of the organism.. They not only carry information about the state of physical fitness of students, and assist the teacher in the selection of exercises, the preparation of standards for musculoskeletal system tests, tracking over time the changes in the physical condition, on the basis of which the achieved results will be evaluated (6-8). Reliable data on physical capacity and determination of the functional state of the organism, reflect the achieved level of physical

\footnotetext{
*Correspondence to: Petya Angelova, Trakia University, Medical College, Bulgaria, Stara Zagora 6003, Georgi Apostolov str. 14, E_mail: pe_angelova@abv.bg,phone number: $+359886441285$
}

capabilities and the degree of development of human Musculoskeletal qualities. Attempts to establish the influence of physical development on physical capacity made by a number of authors - (9-12) provide information about the functional state of the body in students, determined by quantitative results, determining the degree of physical development. Some physiometric indicators lag behind modern youth, and indicators that are correlated with height and weight are reported as improved.

\section{METHODS}

The aim of the study is to determine the individual physiometric parameters in students. The following tasks are set for the realization of the set goal:

- to study and select tests that give objective information about the physical fitness of the student;

- $\quad$ to conduct the research;

- to analyze the obtained results.

The contingent of the study are a total of 130 first and second year female students from the Faculty of Economics, Faculty of Agriculture and Faculty of Veterinary Medicine, included in the compulsory training in physical education at the Thracian University, city of Stara Zagora. The survey was conducted during the 2018/2019 school year. 


\section{METHODS}

- analysis of the scientific and methodological literature;

- anthropometric measurements;

- dynamometry;

- mathematical and statistical methods for quantitative evaluation of the studied indicators and comparative analysis of the obtained results.

In the present comparative study, the following tests were applied to determine the physical fitness of students: anthropometric measurements of height $(\mathrm{cm})$, body weight $(\mathrm{kg})$; vital capacity $(\mathrm{ml})$; left and right hand dynamometer $(\mathrm{kg})$, strength indicator $(\%)$, power looms $(\mathrm{kg})$.

\section{RESULTS}

The average value of vital capacity, published by Slanchev (1992), in women 21 years of age is $3247.3 \mathrm{ml}$., and the average value of the vital capacity in the group studied by us is $3600 \mathrm{ml}$. (Table 1), and this confirms their observation of an upward trend. Normal values of vital signs, which are the ratio between lung capacity and body weight, are $\geq 50$ cubic $\mathrm{cm}$ for women (Table 1). The average value of the vital indicator in the studied students is 61.61, which is more than the normal value (Table 1).

\section{Table 1. Measurement results}

\begin{tabular}{lc|c|c|c|c|c} 
& $\mathrm{N}$ & Mean & $\begin{array}{c}\text { Minimu } \\
\mathrm{m}\end{array}$ & $\begin{array}{c}\text { Maximu } \\
\mathrm{m}\end{array}$ & Range & $\begin{array}{c}\text { Std. } \\
\text { Deviation }\end{array}$ \\
\hline Years & 130 & 19,79 & 18 & 34 & 16 & 1,56 \\
\hline Body weight & 130 & 59,89 & 42 & 106,30 & 64,30 & 11,83 \\
\hline Viral indicator & 130 & 61,61 & 19,76 & 114,61 & 94,84 & 17,85 \\
\hline Vital capacity & 130 & 3,60 & 1,37 & 6,34 & 4,97 &, 93 \\
\hline Dynamometry - left hand & 130 & 12,76 & 4 & 26 & 22 & 4,61 \\
\hline $\begin{array}{l}\text { Dynamometry - right hand } \\
\text { Deadlift }\end{array}$ & 130 & 15,46 & 4 & 29 & 25 & 4,67 \\
\hline $\begin{array}{l}\text { Strength of the back and hip } \\
\text { muscles }\end{array}$ & 130 & 63,42 & 18 & 110 & 92 & 12,88 \\
\hline
\end{tabular}

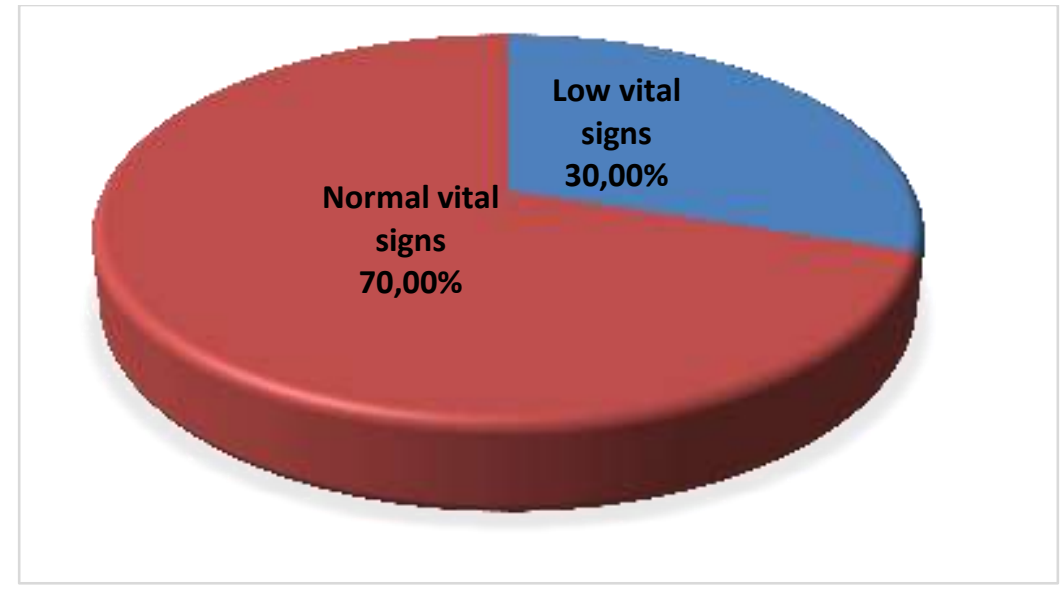

Figure 1. Distribution of relative shares of students by vital signs

The relative share of the studied group with normal vital signs is $70.00 \%$, and the relative share of students with low vital sign $-30.00 \%$ and this is illustrated in Figure 1.

In the dynamometry of the left and right hand average values are found for the right hand $15.46 \mathrm{~kg}$. and for the left $-12.76 \mathrm{~kg}$. Slancev, P. (1992) are indicated strength of the right hand $-35.3 \mathrm{~kg}$. , for the left hand $-37 \mathrm{~kg}$. and it is specified that there is a deterioration in the strength of the hands. The strength indicator data is - left hand 21.61 and right hand 26.27. The norm for women is $45-50 \%$. The relative share of students with a low strength index for the right hand is extremely high $99.23 \%$, and for the right hand is $100 \%$ and this is presented on Figure 2 and 3. 


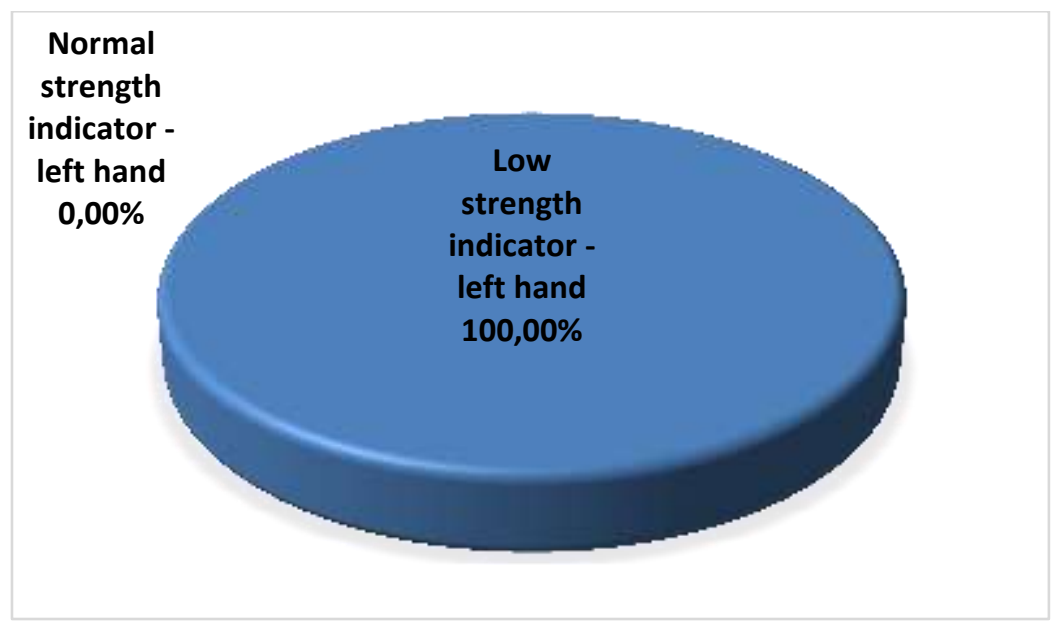

Figure 2. Distribution of relative shares of students by left hand strength indicator

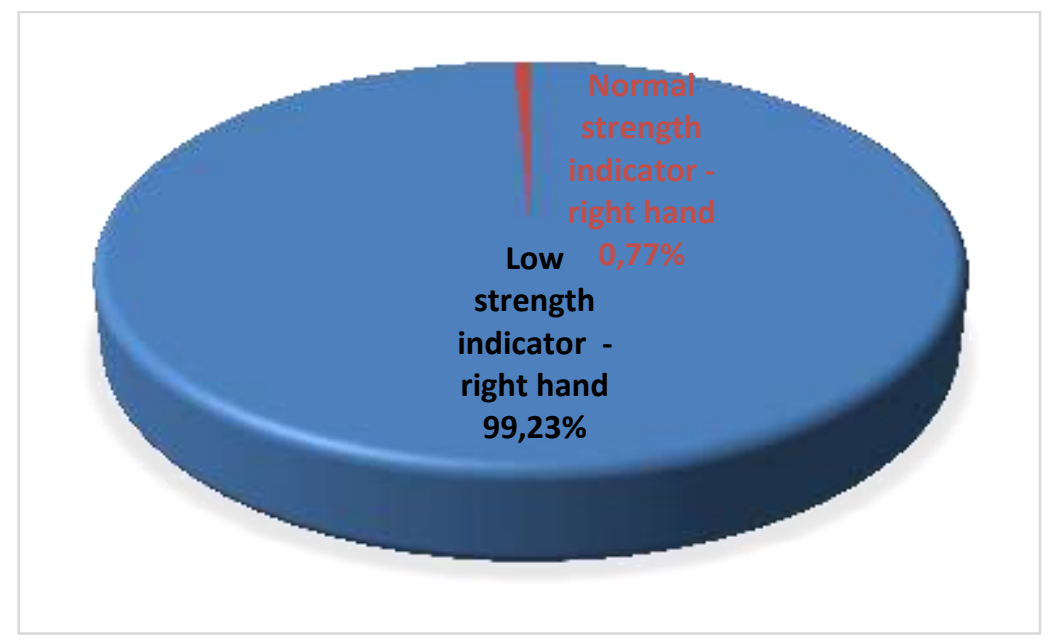

Figure. 3 Distribution of relative shares of students by right-hand strength indicator.

The deadlift indicator has established low values, reflected on Table $\mathbf{1}$. The average value of the looms strength $63.42 \mathrm{~kg}$ (Table 1) according to the norm for women refers to a light strength (below 125\%). The relative share of students with low deadlift is $74.62 \%$, and to those with a deadlift below the average
$16.15 \%$, with an average strength of only $8.46 \%$, and with great strength are only $0.77 \%$, and this is set out in Figure. 4. According to measurements from Slanchev (1992) there is also deterioration in looms strength. Measurement of the strength of the back and hip muscles shows 108.64. (Table 1).

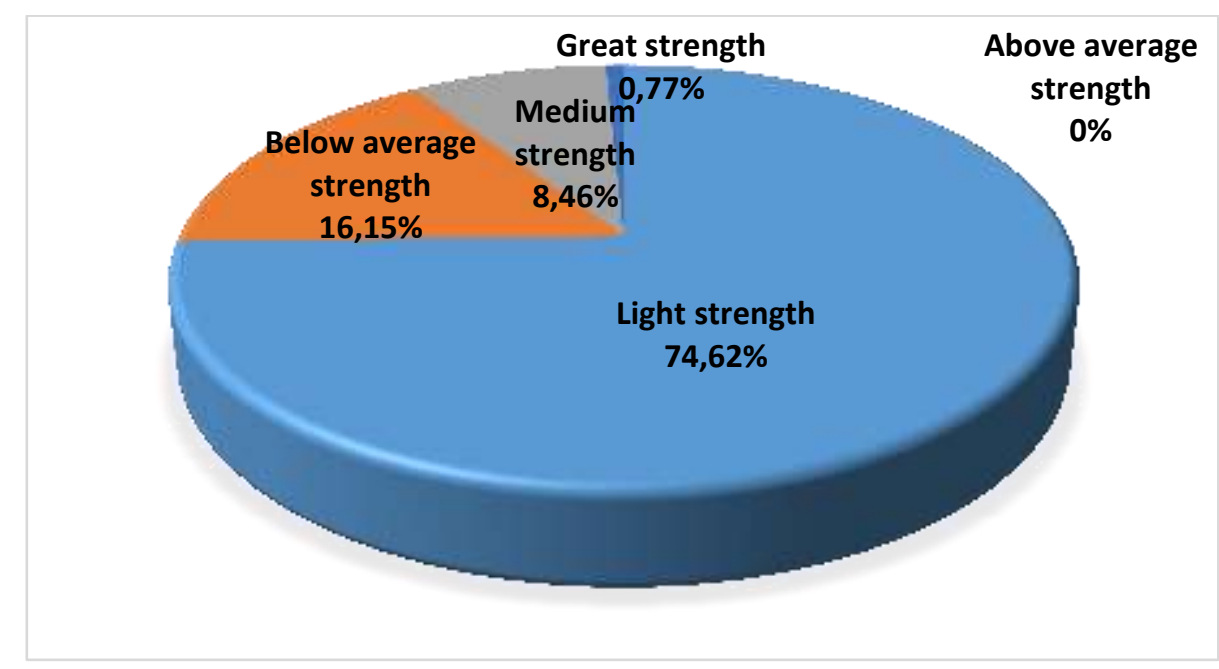

Figure 4. Distribution of relative shares of students by indicator of strength. 


\section{CONCLUSION}

The relative share of students with low vital signs is large. The strength values in the dynamometry are also low. There is a disproportion between good physical development, due to the factors of acceleration and registered retention or deterioration of physical capacity.

The established results can serve to raise awareness on the status of the indicators examined, for follow-up and comparison in further periodic tests. Data on changes in physical development and capacity in general are needed for the education system and in particular for physical education and sports.

\section{REFERENCES}

1. Davidenko, D. N., Zdorovye i obraz zhizni studentov, YU. N. Shchedrin, V. A. Shchegolev. SPb.: SPbGU ITMO, 12, 2005

2. Dyakova, G., Normativi za otsenka na fizicheskata godnost na studenti. Sport $i$ nauka, ISSN 1310-3303, S., izv. br. 1, 581586, 2007

3. Zheleznyak, YU. D., Fizicheskaya aktivnost i zdorovye studentov vuzov nefizkulturnogo profilya, A. V. Leyfa. Teoriya $i$ praktika fizicheskoy kultury. № 12, 46-47, 2006

4. Baronenko, V. A., Zdorovye i fizicheskaya kultura studenta, L. A. Rapoport. Moskva: „Alfa - M“, 352, 2003

5. Rapoport, L. A., Perspektivy razvitiya studencheskogo sporta $\mathrm{V}$ universitetakh Rossii: monografiya. Ekaterinburg: GOU VPO UGTU - UPI, 356, 2004

6. Dyakova, G., Barokova, M., Izsledvane na fizicheskata godnost na studenti ot Trakiǔski universitet. Trakia Journal of Sciences, The Scientitific Serial of Trakia University, ISSN 1312-1723, Vol. 3, 37-40. 2005

7. Dyakova G, Lapadatov, L., Sravnyavane na pokazateli za fizicheska godnost pri studenti. Nauchni trudove na Rusenskiya Universitet, tom 54, seriya 8.2, 2015

8. Plyakov, S., Testovata bateriya „Evrofit"“ kato metodologicheska baza pri izgotvyane
ANGELOVA P., et al.

na edinni standarti $\mathrm{v}$ oblastta na fizicheskoto vazpitanie i sporta. Eastern Academic Journal.ISSN: 2367-7384, Issue 1, 1-7, 2017

9. Dyakova, G., Peeva, P., Bozhkova, A., Izsledvane variativnostta na fizicheskite kachestva i morfofunktsionalnite pokazateli na studenti ot Trakiyski universitet. Sport $i$ nauka, ISSN 1310-3303, Sofiya, izv. br. 1, 587-592, 2007

10.Jorgić, B., Đorđević, S., Belomazeva, S., Milenković, S., Tsonkova, D., Georgiev, G., Kostić, S., Postural Status of the Spinal Column in the Sagittal Plane in a Student Population. Book of Proceedings XIX International Scientific Conference,,FIS Communications 2016" in physical education, sport and recreation, Nis, 2016

11.Bozhkova, A., Izsledvane variativnostta na fizicheskite kachestva i morfofunktsionalnite pokazateli na studentki po dentalna meditsina, Nauchni trudove na Rusenskiya Universitet - 2013, tom 52. seriya 8.2 - 58 - Univ. izd. „Sv. Kliment Ohridski”, 7-15, ISSN 1314-2275, 2013

12.Doncheva, M., Dobreva, Y., Izsledvane sastoyanieto na pokazateli za fizicheska deesposobnost $\mathrm{v}$ zavisimost ot antropometrikata na studenti ot TU - Varna 2013, Nauchni trudove na Rusenskiya Universitet, tom 52. seriya 8.2, 2013

13.Ilinich, V. I., Fizicheskaya kultura studenta, Moskva: „Gardariki“ , 448, 2005

14. Yordanov, S., Yordanov, E., Tenev, D., Fizichesko razvitie i fizicheska godnost na studenti, uchashti $\mathrm{v}$ kurs po nachalna voenna podgotovka na Ministerstvoto na otbranata. Nauchni trudove na Rusenskiya Universitet, Tom 53, seriya 8.2, 2014

15.Slanchev, P., Yanev, B., Genov, F., Shterev, P., Boev, P., Sepetliev, Zahariev, B., Fizichesko razvitie fizicheska deesposobnost i nervno-psikhicheska reaktivnost na naselenieto na Balgariya, NI (19980-1982), BSFKS, Sofiya, 30-31, 1992 